\title{
Consumption of Bushmeat in Lubumbashi/DR Congo: Sociocultural Approaches
}

\author{
K. M. Tshikung ${ }^{1}$, S. E. W. Pongombo ${ }^{1}$, L. Roland ${ }^{2}$ and J. L. Hornick ${ }^{2}$ \\ 1. Faculty of Veterinary Medicine, University of Lubumbashi, Lubumbashi 1825, DR, Congo \\ 2. Faculty of Veterinary Medicine, University of Liège, Liège 4000, Belgium
}

\begin{abstract}
Bushmeat is frequently consumed in households in the city of Lubumbashi in the Democratic Republic of Congo. Several studies in Africa show that this food is regularly consumed by rural and urban populations. This consumption is motivated by several reasons. These have never been elucidated in the city of Lubumbashi. This study aims to highlight the sociocultural aspects that justify the consumption of bushmeat in order to consider its sustainability. A survey was conducted among 1,400 households in the municipalities of the city. A questionnaire helped collect the information that was presented as a percentage. This information shows that $86.6 \%$ of the population consume monthly (41.3\%) of bushmeat. This consumption is based on taste (51.7\%). On the other hand, religious beliefs (29.2\%) prevent this consumption. The order of the artiodactylsis is the most affected (74.2\%). The recognition of the species consumed comes from the information provided by the sellers (58.5\%). Bushmeat comes from the district of Haut-Katanga (35.2\%). It is sold in the main markets of the city of Lubumbashi (67.9\%). Bush meat is becoming an exhaustible natural resource, mechanisms and alternatives will need to be put in place to enable the sustainable conservation of wild animal species.
\end{abstract}

Key words: Consumption, bushmeat, sociocultural.

\section{Introduction}

Bushmeat has been consumed by many African communities for decades [1]. It is obtained, on the one hand through traditional hunting or subsistence and on the other hand, in commercial hunting, as a cultural and social symbol. It plays a crucial role in the food of people living in rural areas because it is their main source of protein $[2,3]$. In urban area, it is sold in markets and is also frequently consumed in households [4].

The consumption of bushmeat is often customary. Commercial hunting is an activity that aims to generate financial resources [5-7]. As such, it has become the most important threat to the survival of wildlife [8].

Large quantities of bushmeat are traded in the markets of several African cities, encouraging

Corresponding author: TSHIKUNG KAMBOL MOSSES DIDIER, Ph.D., professor, research fields: wildlife management and bushmeat. continued consumption [9]. The cities of DR Congo are not on the sidelines. Unfortunately, the quantities of bushmeat consumed or marketed are hardly known and evaluated. The socio-cultural parameters of bushmeat consumption are also unclear in the province of Greater Katanga in general and in the city of Lubumbashi in particular.

Beyond the benefits of supplying the town of Lubumbashi with game, there is a fear of their unsustainable use $[8,10]$ because, like large urban centers, the city in Lubumbashi is characterized by a rapid population growth resulting mainly from population migration accompanied by significant social and cultural mixing [3]. According to the report of the town hall [11], the inhabitants of the city of Lubumbashi have increased from 150,000 to about $5,000,000$ individuals resulting in a probable increase in demand for bushmeat by potential consumers [12]. As a result, overexploitation of wildlife resources in a post-conflict context in the Democratic Republic of 
Congo would result in the long-term loss of many animal species. In this respect, overexploitation of wildlife is the most worrying aspect of its biological, economic and social consequences [13]. In fact, there is a biological decline in numbers; economically, a decrease in financial benefits due to lack of tourism activities; and from a social point of view, negative consequences for the health, well-being, cultural and spiritual identity of local communities dependent on the forest.

Commercial hunting can cause unsustainable exploitation of game [14]. This trend is based on the amount of bushmeat sold in urban markets or consumed by families [15]. It turns out that the consumption of bushmeat is important and that economic activities related to this food can therefore lead to serious threats to African wildlife. The sustainability of bushmeat is not incompatible with the conservation and protection of wildlife, but it is a matter of substance [10]. One study indicates that game consumption per $\mathrm{km}^{2}$ per year is about three times higher in the Democratic Republic of the Congo than in neighboring forest countries [10]. Similarly, [12] estimate that the amount of game meat harvested each year in the Congo Basin is estimated at 5 million tones. This reflects the threat to wildlife and the economic activity associated with it.

The balance between wildlife conservation and people's food needs are major challenges in several African countries [16]. Thus, this study aimed to identify the place of socio-cultural parameters in the choices and habits of consumers of bushmeat.

\section{Method}

The present study was carried out in the seven communes of the city of Lubumbashi (Annex, Kamalondo, Kampemba, Katuba, Kenya, Lubumbashi and Ruashi) subdivided into 43 districts (Fig. 1). The city is located between $11^{\circ} 30^{\prime}$ and $11^{\circ} 50^{\prime}$ south latitude and $27^{\circ} 17^{\prime}$ and $27^{\circ} 40^{\prime}$ east longitude [17]. It is the capital of the province of Katanga. This city is under a tropical subhumid climate characterized by the alternation of a rainy season (November to April) and a dry season (May to October). From an annual average of $20{ }^{\circ} \mathrm{C}$, the temperatures vary from 16 to $33{ }^{\circ} \mathrm{C}$; the month of July is the coldest and October the hottest $[18,19]$. The average annual rainfall is

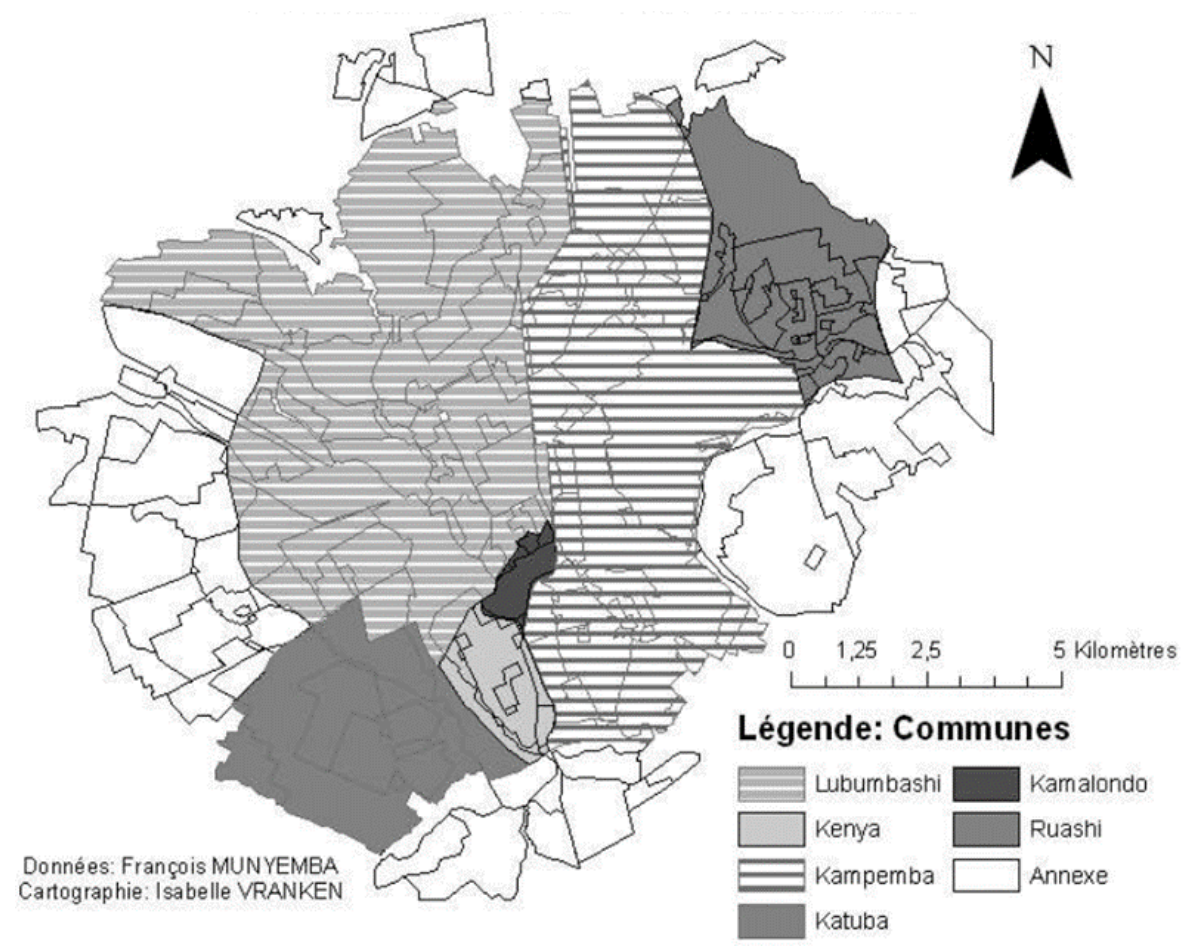

Fig. 1 Location of the seven communes constituting the city of Lubumbashi [17]. 
about 1,270 mm and humidity varies between 55 and 85\% (January being the wettest, July, August and September the least humid) [20].

For data collection, field work was conducted with bushmeat consumers. It is the households that constituted the field of investigation. The investigations lasted for six months, from December 2008 to May 2009; based on an open and closed questionnaire that consisted of two parts. The first part aimed to identify the profile of bushmeat consumers and the second part to identify socio-cultural motivations related to bushmeat consumption.

A total of 1,400 index cards, one for each household, have been distributed. Households were selected using the cluster sampling method. This sampling was preferred because of the extent of the city of Lubumbashi and to reduce travel costs. We have clustered neighborhoods $(n=43)$ of the city of Lubumbashi. The elements of these clusters were then randomly selected. A list has been written. It served as a sampling frame. Regarding the correlation between socio-cultural parameters of the population in Lubumbashi and meat consumption, a Multiple Correspondence Analysis (MCA) was performed using the XLSTAT software version 7.5.2.

\section{Results}

The socio-demographic characteristics of the people surveyed are reported in Tables 1 and 2 and socio-cultural approaches related to bushmeat consumption in Tables 3-5. Two figures present the analyses of the MCA in relation with the motivation of the consumption of the bushmeat by the populations of the city of Lubumbashi (Fig. 2 and Fig. 3).

Table 1 Sociodemographic characteristics of the respondents.

\begin{tabular}{|c|c|c|}
\hline Characteristics & $N=1,400$ & $\%$ \\
\hline \multicolumn{3}{|l|}{ Sex } \\
\hline Male & 1,113 & 79.5 \\
\hline Female & 287 & 20.5 \\
\hline Agerange (years) & 8 & 0.57 \\
\hline \multicolumn{3}{|l|}{ Less than 25} \\
\hline $26-40$ & 328 & 23.4 \\
\hline $41-55$ & 474 & 33.8 \\
\hline 56 and over & 590 & 42.1 \\
\hline \multicolumn{3}{|l|}{ Maritalstatus } \\
\hline Single & 0 & 0 \\
\hline Married & 953 & 68 \\
\hline Divorced & 345 & 24.6 \\
\hline Widower and widow & 102 & 7.3 \\
\hline \multicolumn{3}{|l|}{ Levelofeducation } \\
\hline Primary & 301 & 21.5 \\
\hline Secondary & 593 & 42.3 \\
\hline University & 506 & 36.1 \\
\hline \multicolumn{3}{|l|}{ Number of people in charge } \\
\hline $0-3$ & 144 & 10.2 \\
\hline $4-6$ & 196 & 14 \\
\hline $7-10$ & 703 & 50.2 \\
\hline 11 and over 11 & 357 & 25.5 \\
\hline Religion & 752 & 53.7 \\
\hline \multicolumn{3}{|l|}{ Catholic } \\
\hline Protestant & 501 & 35.8 \\
\hline Muslim & 147 & 10.5 \\
\hline
\end{tabular}


Table 2 Distribution of respondents by province of origin.

\begin{tabular}{lll}
\hline Province & Number $(n=1,400)$ & $\%$ \\
\hline Bandundu & 84 & 6 \\
Bas-Congo & 113 & 8 \\
Equateur & 24 & 1.7 \\
Katanga & 309 & 22 \\
Kasai-oriental & 265 & 18.9 \\
Kasai-Occidental & 193 & 13.8 \\
Maniema & 172 & 12.3 \\
Nord-Kivu & 103 & 7.4 \\
Province-Orientale & 76 & 5.4 \\
Sud-Kivu & 61 & 4.4 \\
\hline
\end{tabular}

Table 3 Distribution of respondents according to consumption parameters of bushmeat.

\begin{tabular}{|c|c|c|}
\hline Parameters & $(n=1,400)$ & $\%$ \\
\hline \multicolumn{3}{|l|}{ Consumption } \\
\hline Yes & 1,212 & 86.6 \\
\hline No & 154 & 11 \\
\hline Other & 34 & 2.4 \\
\hline Reason for consumption $(n=1,212)$ & 403 & 33.2 \\
\hline \multicolumn{3}{|l|}{ Foodstuff } \\
\hline Custom & 92 & 7.6 \\
\hline Taste & 627 & 51.7 \\
\hline Other & 90 & 7.4 \\
\hline \multicolumn{3}{|l|}{ Reason for non-consumption $(n=154)$} \\
\hline Expensive & 35 & 22.7 \\
\hline Custom & 19 & 12.3 \\
\hline Identification problem & 14 & 9.1 \\
\hline Source of diseases & 25 & 16.2 \\
\hline Religious Beliefs & 45 & 29.2 \\
\hline Vegetarian & 1 & 0.6 \\
\hline Other & 15 & 9.7 \\
\hline \multicolumn{3}{|l|}{ Frequency of consumption $(n=1,212)$} \\
\hline 1 time/month & 500 & 41.3 \\
\hline 2 times/month & 223 & 18.4 \\
\hline 3 times/month & 272 & 22.4 \\
\hline Other & 217 & 17.9 \\
\hline
\end{tabular}

Table 4 Distribution of respondents according to the order of the species consumed and the identification of the species from the pieces of meat bought on the market.

\begin{tabular}{lll}
\hline Parameters & $(n=1,212)$ & $\%$ \\
\hline Order of consumed species & & \\
\hline Artiodactyls & 900 & 74.2 \\
Perissodactyla & 24 & 2 \\
Pholidota & 27 & 2.2 \\
Proboscidians & 25 & 2.1 \\
Primates & 142 & 11.7 \\
Rodents & 94 & 7.8 \\
Bats & 0 & 0 \\
\hline
\end{tabular}


Table 4 to be continued

\begin{tabular}{lll}
\hline Identification of the species & & \\
\hline Taste & 0 & 0 \\
Consistency & 0 & 0 \\
Anatomical organs & 503 & 41.5 \\
Sellers & 709 & 58.5 \\
\hline
\end{tabular}

Table 5 Distribution of respondents by source of supply.

\begin{tabular}{llllll}
\hline & \multicolumn{2}{l}{ Places of obtaining Meat } & \multicolumn{2}{l}{ Locations of meat } \\
\hline Places & Workforce & $\%$ & Workforce & & $\%$ \\
& $(n=1,212)$ & & & $(n=1,212)$ & 35.2 \\
\hline Market & 823 & 67.9 & Upper Katanga & 427 & 29.3 \\
House & 293 & 24.1 & Upper Lomami & 355 & 9.2 \\
Route & 7.9 & Likasi & 111 & 7.9 \\
& & & Lualaba & 90 & 6.5 \\
& & Kolwezi & 79 & 6.5 \\
& & Southern Africa & 79 & 4.9 \\
\hline
\end{tabular}

\section{Graphique symétrique}

(axes F1 and F2 : $46.01 \%$ )

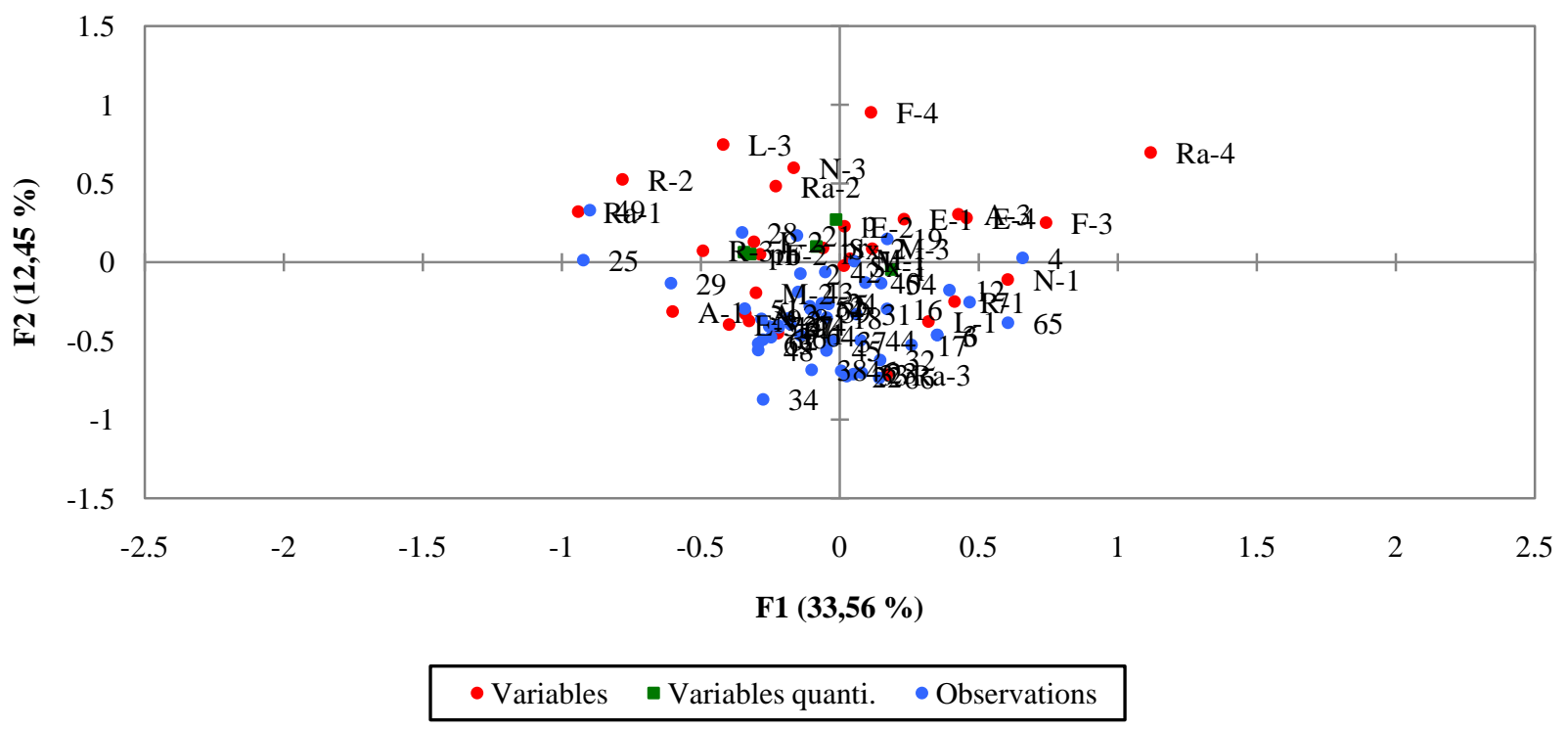

Fig. 2 Effects of socio-cultural parameters on bushmeat consumption (MCA, axis 1 and 2). 


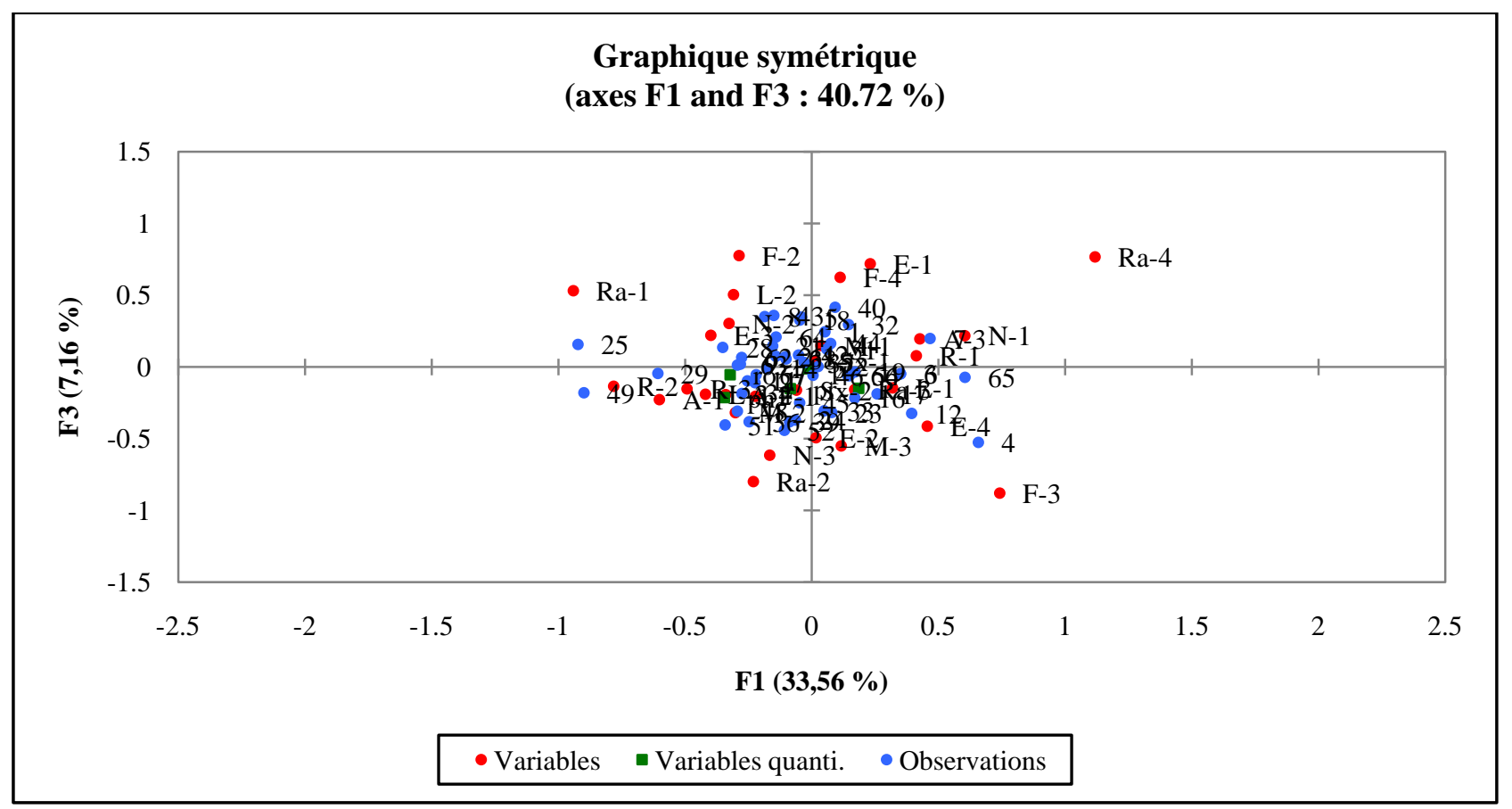

Fig. 3 Effects of socio-cultural parameters on bushmeat consumption (MCA, axis 1 and 3).

\section{Discussion}

Concerning the profile of the respondents, we find that several households are headed by men, aged 56 and over. They are married and have several children; they have also a medium level of education. They are mainly from the province of Katanga. But people from the two provinces of Kasai put together are the majority with $32.7 \%$. These results correspond to a certain extent to those presented in some studies of African regions [21, 22]. These characteristics give an impression on the link between populations and their customs; although living in an urban environment. Indeed, the statements of the respondents reflect their belonging to the cultural and social conditions attached to their customs.

Out of 1,400 households surveyed, 86.6\% consume bushmeat compared to $11 \%$. Among the reasons mentioned by consumer households, there is the taste and the fact that it is an edible food. On the other hand, the arguments relating to non-consumption are also numerous, the most prominent are religious beliefs, prices, diseases and customs (taboos). These reasons slow down the consumption of bushmeat. These results are consistent with those supported by Ref. [23] who estimates that in Ghana, 70\% of the population eat bushmeat. According to Ref. [24], the consumption of bushmeat in Côte d'Ivoire is estimated at $86 \%$ of the rural population, compared to $77 \%$ of the urban population (i.e. $87.7 \%$ of the population). Also the survey at the DABAC project level [25] in Libreville shows firstly that a proportion of $64 \%$ of the sample of interviewees are a game lover against $10 \%$ who do not appreciate it at all.

Taste is the major element that conditions this consumption. Indeed, Ref. [26] shows that $49 \%$ of consumers of this food product are attracted by taste $25 \%$ by habit and $21 \%$ by cultural attachment. In the same way, Ref. [27] reports that $36 \%$ of respondents believe that meat is delicious while $20 \%$ and $18 \%$ believe that it presents less risk of disease and is rich in nutrients.

The taste of bushmeat is appreciated by the majority of the population. It tastes particularly appetizing according to consumers. Consumer demand for "tasty" foods is evident [28]. The taste, and more broadly all the organoleptic aspects occupy an essential place in the food. Without taste, we cannot be able to choose 
the food necessary to cover our food needs [29].

Other arguments contrary to our results justify the demand for bushmeat for reasons related to eating habits, tradition and the desire to vary the menus [30, 31]. Ref. [32] adds that the reasons for this predilection are dictated by dietary, financial and symbolic concerns. In this regard, the Hunters Survey also reveals that almost $50 \%$ of the rural population and one third of the urban population in Côte d'Ivoire choose bushmeat for its easy access; one-third of the rural and urban population by preference; a quarter of the rural population by habit; and $10 \%$ of the rural population for its low price. Other people eat bushmeat to establish a certain social status [33]. While others consider this food as natural and a cultural heritage [34].

In terms of price, the results reveal that $22.7 \%$ of respondents believe that meat is expensive and, as such, it is difficult to integrate the high price of bushmeat into their budget because of the low purchasing power. The price depends on the environment in which the consumer is. In rural areas, it seems to be lowthan in urban areas. As Ref. [35] estimates, the consumption of game is decreasing and the main limiting factor is the price. This varies according to the species exposed and the nature of the bushmeat [36]. As a result, bushmeat has become a luxury product, a fashion and a true market economy in cities [37].

Religion is also consideredas one of the factors that prevent the consumption of bushmeat. Some religious beliefs prevent the consumption of a certain type of meat to their followers. They believe that eating indexed meat would be a sin. In addition to religion, bushmeat is not consumed for reasons of disease and the difficulty of identifying the species that are proposed. Some informed consumers know that wildlife is a potential reservoir of diseases that can be transmitted to humans, hence their mistrust. The other aspect is that the consumer is not sure of eating the species he wants. Especially since the meat is presented in most cases, in the form of pieces. Identification information usually comes from the seller. It is obvious that the reasons for or not eating bushmeat are multiple and depend on individuals, culture, beliefs and society.

The frequency of meat consumption is once a month. This frequency corroborates with that of Ref. [30] who reports that consumption is not constant and that $39 \%$ of the people met consume game once a month. In the same context, the Chasseurs surveys in Côte d'Ivoire cited by Ref. [24] show that $43 \%$ of the urban population consume game only once a month. Our results are in the order of $41.3 \%$. In contrast, for [38], 72\% of Bukavu's population regularly ate bushmeat. We believe that the frequency depends on several factors including accessibility, the environment and the species proposed.

Taking into account the species sold in the markets of the city of Lubumbashi, the results show that the artiodactyls with $74.2 \%$ are the most consumed. This shows how much they are most exposed to extinction, compared to other mammals. It must be said that the vocal "antelope", according to the households surveyed is understood as the artiodactyls except the families of suids, hippopotamids and cattle. These results are consistent with those of Refs. [3, 33, 39] who estimate that the most slaughtered species in Central Africa are antelopes or mammals in general. Thus, the contribution of artiodactyls in the total biomass taken is often considered remarkable [3, 40]. The reason for their presence at the markets level is that antelopes are the most important game numerically and biomass. On the other hand, rodents gain importance in urban markets in Africa probably because antelopes are being decimated in nearby forests [41]. Our results show that $7.8 \%$ of the species consumed are rodents. Ref. [3] estimates them at 9.1\%. These species seem to replace big game in urban centers. It would be interesting to look at this activity which could eventually reduce rodent biomass.

In this perspective, other results contrary to ours 
include those published by the DABAC project in Libreville, which state that the preferred species are athérures (42\%), bush pig (22\%), antelopes (18\%) and primates (5\%). In the southeastern region of Côte d'Ivoire, the big grasscutter is the favorite game followed by the Athérure, giant Emin rat, duikers and monkeys. The latter, especially the great apes, are the least preferred because of their resemblance to humans and the fact that they may carry disease [24].

These differences can be explained by the availability of species in markets and even in forests. As large fauna is decreasing more and more in many parts of Africa, it should be noted also, the domestication of certain species including the great grasscutter and the rat of Gambia for example in West Africa, the size of the animal and finally, the tradition and the culture of the consumers.

The identification of the purchased species is based on the information transmitted from one actor to another in the sector. The information goes from the hunter through the suppliers and lands at the vendors. The latter, at the time of sale, are the ones who inform consumers. However, the persistence of certain morphological characteristics, in particular the hoof, the anterior and posterior limbs of the artiodactylsand primates can allow a reliable identification but limited to the genus or even to the family. In general, the identification is random and does not favor specifying the species consumed [42]. This has negative implications for the management of the wildlife population.

The households surveyed indicate that the origin of bushmeat is so diverse. These results are similar to those published in Yaoundé, who consider that game has various origins [43]. Indeed, we see in Table 5 that several former districts of greater Katanga, other provinces of the country and southern Africa are involved. Among the districts of Katanga, that of Haut-Katanga with $35.2 \%$ stands out. This situation is explained by the proximity of the majority of its territories to Kundelungu and Upemba National Parks.
Access to these protected areas is easy, sometimes with the blessing of rangers. These are territories that have experienced armed conflict. Parks have served as a place of refuge for armed gangs and even the people.

Bushmeat also comes from other provinces through travelers, and from some countries in southern and eastern Africa, including Zambia, Tanzania, South Africa and Angola. There is some international traffic with all the risks to public health and the animal economy. The bushmeat trade is becoming more and more internationalized [44].

The places of power or purchase of game meat are the markets, at home and on the road. The majority of households in the city of Lubumbashi obtain foodstuffs in the markets. Some suppliers go door-to-door to sell bushmeat. But some families receive pieces of meat from their relatives from different rural areas. Traveling people also have the opportunity to buy fresh or smoked meat directly on the road.

The above paragraphs show that socio-cultural aspects are reported as reasons for consumption of bushmeat. To immerse in this reality, the MCA analyses were carried out. This statistical test was applied to realize the effectiveness of the influence of socio-cultural approaches on the consumption of bushmeat. The MCA indicates that there is no correlation between these two variables. Factors beyond axis 3 have not been interpreted because the other factor axes give little indication. Thus, Figs. 1 and 2 show the first three factorial axes. It emerges that there is no correspondence between socio-cultural approaches and the consumption of bushmeat. Indeed, the graphs indicate that the modalities are very close to the origin of the axes and do not make it possible to conclude that there is a correspondence. This may mean that bushmeat is not consumed solely on the basis of social or cultural trends. Other elements may come into play including organoleptic aspects.

\section{Conclusion}


Game meat is consumed by most households in the city of Lubumbashi. However, mismanagement of the largely uncontrolled exploitation of wild animals threatens to eradicate this precious resource. This extinction will deprive millions of people, especially rural populations, of a vital source of animal protein. It will also end up depriving people engaged in the wild meat trade, commonly known as bushmeat, from their livelihood. In the longer term, the extinction of species will lead to the collapse of forest ecosystems.

The consumption of game meat in Lubumbashi was analyzed, with a special focus on the various socio-cultural parameters, including the consumption of bushmeat, its reasons, its frequency, the species consumed, their identification, provenance and the trading venues. This analysis reveals that bushmeat is widely consumed in the city of Lubumbashi. However, the social and cultural reasons do not justify this consumption alone. On the one hand, the organoleptic characteristics are at the base of this consumption. On the other hand, religious beliefs are among the factors that slow down this practice. The species of the order Artiodactyls are the most consumed. The frequency is once a month.

This game meat comes mainly from the district of Haut-Katanga but also from other provinces of DR Congo and bordering countries including Zambia, Tanzania and Angola. Consumers buy this food in the city's markets.

It is now undeniable in light of the results published in this study, that the harvesting of wild animal resources must be controlled from a long-term management perspective. This involves mechanisms for monitoring bushmeat in Lubumbashi, as well as the regulation of marketing. Policy makers have an obligation to consider aspects that are both conservation and sustainable development.

\section{References}

[1] Makosso, G. V., Massamba, J., Massamba A., and Silou, T. 2011. "Consumption of Bushmeat in the Conkouati-Douli National Park Area, Congo
(Brazzaville): Nature of the Game and Consumption Patterns.” Tropicultura 29 (3): 131-7.

[2] Auzel, P. 2007. "What Alternatives to Bushmeat in Central African Logging Concessions.” Info Traffic 8.

[3] Semeki, J. N., Belani, J. M., Ntoto, R. M., and Vermeulen, C. 2014. "Consumption of Products of Animal Origin in the Forest Concession 039/11 of SODEFOR in Oshwe (DR Congo).” Tropicultura 32 (3): 147-55.

[4] SCBD. 2009. "Biodiversity, Development and Poverty Reduction: Recognizing the Role of Biodiversity for Human Well-Being.” Montréal.

[5] Fargeot, C. 2004. "Commercial Hunting in Central Africa: The Venaison or the Trade of a Fish Product." Forests of the Tropics 40 (282): 27-40.

[6] Willcox and Nambu. 2007 "Wildlife Hunting Practices and Bushmeat Dynamics of the Banyangi and Mbo People of Southwestern Cameroon.” Biological Conservation 134 (2): 251-61.

[7] Kümpel, N. F., Milner-Gulland, E. J., Cowlishaw, G., and Marcus Rowcliffe, J. 2010. "Incentives for Hunting: The Role of Bushmeat in the Household Economy in Rural Equatorial Guinea.” Human Ecology 38 (2): 251-64.

[8] FRM. 2009. Supply Inventory Report 28/03 Nteno-SODEFOR. Kinshasa, p. 84.

[9] Mbete, R. A., Banga-Mboko, H., Ngokaka, C., Bouckacka, Q. F., Nganga, I., Hornick, J. L., Leroy, P., and Vermeulen, C. 2011. "Profile of hunt meat sellers and evaluation of biomass marketed in the municipal markets of Brazaville, Congo, Mongabay.com.” Open Access Journal-Tropical Conservation Science 4 (2): 203-17.

[10] Wilkie, D. S., and Carpenter, J. F. 1999. "Bushmeat Hunting in the Congo Basin: An Assessment of Impacts and Options for Mitigation.” Biodiversity and Conservation 8 (7): 927-55.

[11] Anonymous, 2013. Annual Report of the State of Population Office, Town Hall of Lubumbashi.

[12] Fa, J. E., Peres, C. A., and Meeuwing, J. 2002. "Bushmeat Exploitation in Tropical Forests: An International Comparison.” Conservation Biology 16 (1): 232-7.

[13] Zecchini, A. 2006. "Bushmeat and Its Exploitation.” Bull de la Soc. Zoo. of Fr. 129: 189-206.

[14] Bardot, B. 2007. Bushmeat and International Trafficking: Threat to Protected Species. Libreville: Brigitte Bardot Foundation.

[15] Ngama, S. 2015. "Quantitative Analysis of Bushmeat Consumption for Sustainable Wildlife Management in Gabon.” Tropicultura, NS, 12-3.

[16] Koulagna, D. K. 2001. "Bush Bushmeat Crisis Tast Force, Silver Spring, MD.” BCTF Collaborative Action Planning Meeting Proceedings. 
[17] Vranken, I. 2010. "Pollution et contamination des sols aux métaux lourds dues à l'industrie métallurgique à Lubumbashi: Empreinte écologique, impact paysager, pistes de gestion (Mémoire de fin d'études).” Université Libre de Bruxelles, Bruxelles.

[18] Shutcha, M. N., Faucon, M. P., Kissi, C. K., Colinet, G., Mahy, G., Luhembwe, M. N., Visser, M., and Meerts, P. 2015. "Three Years of Phytostabilisation Experiment of Bare Acidic Soil Extremely Contaminated by Copper Smelting Using Plant Biodiversity of Metal-rich Soils in Tropical Africa (Katanga, DR Congo).” Ecol. Eng. 82: 81-90.

[19] Erens, H., Boudin, M., Mees, F., Mujinya, B. B., Baert, G., van Strydonck, M., Boeckx, P., and van Ranst, E. 2015. "The Age of Large Termite Mounds-Radiocarbon Dating of Macrotermesfalciger Mounds of the Miombo Woodland of Katanga, DR Congo.” Palaeogeogr. Palaeoclimatol.Palaeoecol. 435: 265-71.

[20] Useni Sikuzani, Y., Mwamba Ilunga, G., and Mwamba Mulembo, T. B. 2014 "Improving the Quality of Lubumbashi (Katanga, RD Congo) Acid Soils by Applying Different Levels of Hog Manure Compost.” Journal of Applied Biosciences 77 (1): 6523-33.

[21] Maadjou, B., Diallo, S. T., Diallo, H., Camara, S., and Sagna, S. 2002. "Plan d'actions pour la conservation de la diversité biologique et l'utilisation durable des ressources.” In: Kasisi, R., Stratégie nationale et plan d'actions sur la diversité biologique, Guinée/PNUD/FEM.

[22] Ndemezogo, M. G. 2009. La commercialization du gibier au Gabon, (Mémoire). Libreville: Université Omar Bongo.

[23] Asibey E. O. A. 1977. "Expected Effects of Land Use Patterns on Future Supplies of Bushmeat in South Africa of the Sahara.” Envir. Cons. 4: 43-9.

[24] Caspary, H. U. 2000. "Wildlife and the Bushmeat Industry in Southeast Côte d'Ivoire.” Humboldt-University Dissertation, Berlin.

[25] Anonymous. 2005. Report of Surveys Conducted in Libreville. DABAC Project, Gabon.

[26] Indjieley, M. “The Meat Sector in Libreville.” APFT News 7: 13-5.

[27] Ouedraogo, A. H. 2007. "Bushmeat in Burkina Faso, West Africa Portal.” January 2007.

[28] Etievant, P. 2006. "Better Understanding of Taste, Alimentation-INRA.” No. 4, September 2006.
[29] Leverve, X. 2006. "Food and taste, Alimentation-Inera." No. 4, September 2006.

[30] Bahuchet, S. 2000. "The Bushmeat Sector, the Peoples of the Tropical Forests Today, Brussels.” APFT 2: 331-63.

[31] Santos, I. 2003. The DABAC project, Alternative to Wild Hunting, MFI HEBDO: Science Technology.

[32] Liliane, D., and Nizesete, B. 2002. "Bushmeat Sector in Adamaoua: Hunting and Consumption." University of Ngaoundéré, Cameroon, Mega-Chad.

[33] Samndong, R. A. 2005. "Bushmeat Hunting and Wildlife Management in the Rainforest of Cameroon.” Tropical Ecology and Management 7: 1-7.

[34] Chardonnet, P. 1995. "African Wildlife, the Forgotten Resource, Tomes 1 and 2." CEE/ IGF, Luxembourg. Chevalier, S. 2010. Daily Life at the Villa Thoreton, the Parisian, Ecology, Gastronomy and Society.

[35] Wilkie, D. S. 2005. Conservation Biology 19 (1): 268-74.

[36] Allebone-Webb, S. M., Kümpel, N. F., Rist, J., Cowlishow, G., Roweliffe, J. M., and Milner-Gulland, E. J. 2010. "The Use of Market Data to Assess Bushmeat Hunting Sustainability: Evidence from Equatorial Guinea.” Conservation Biology.

[37] Grundmann, E. 2009. "Great Apes and Forest: Same Fight for the Planet, Futura Sciences.”

[38] Keita, J. D. 1993. "Non-Wood Forest Products in Africa, Paper Prepared for Regional Expert Consultation on Non-Wood Forest Products for English-Speaking African Countries.” Council Commonwealth Science Council, Arusha, Tanzania.

[39] Bikouya, G. H. 2007. "Use of Hunting Meat around the Future Ogooué-Lékéti National Park: Case of the Ogooué Axis, Zanaga District.” Department of Lékoumou, MARIEM NGOUABI University.

[40] Fargeot, C. 2005. "Commercial Hunting in Central Africa: The Venison or the Trade of a Food Product."

[41] Fa, J. E., Just, J., Perez Del Val, J., and Castroviejo, J. 1995. "Impact of Market Hunting on Mammals in Equatorial Guinea.” Cons. Biol. 9 (5): 1107-15.

[42] Renatura. 2006. "Report of the Bushmeat Survey." Brazzaville.

[43] CWE. 2000. "Poaching and Circulation of Wildlife Products along the Rail (Yaoundé-Ngaoundal Axis).” Report, Yaoundé.

[44] WWF. 2018. In www.mediacongo.net viewed on 15/10/2018 at 10 o'clock. 